\title{
CONTENTS OF VOLUME 31
}

RASAJIT KUMAR BERA: Nonlinear oscillations and buckling of anisotropic cylindrical shells under large initial stresses

A. L. CAREY and K. McNAMARA: Degenerate forms of Maxwell's equations

IAN D. COOPE: A conjugate direction implementation of the BFGS algorithm with automatic scaling

ANDREW COYLE: Sensitivity bounds on a $G I / M / n / n$ queueing system

J. P. DENIER and R. GRIMSHAW: Slowly-varying bifurcation theory in dissipative systems

J. P. DENIER and R. H. J. GRIMSHAW: Nonlinear interaction of positive and negative energy modes in Hamiltonian systems

J. N. DEWYNNE, S. D. HOWISON, J. R. OCKENDON and WEIQING XIE: Asymptotic behavior of solutions to the Stefan problem with a kinetic condition at the free boundary

B. DUSZCZYK: See S. KOSINSKI

SUZANNE P. EVANS: A mathematical model and related problems of optimal management and design in a broadband integrated services network

R. GRIMSHAW: See J. P. DENIER

A. J. HALL and G. C. WAKE: Functional differential equations determining steady size distributions for populations of cells growing exponentially

W. HENDERSON, D. LUCIC and P. G. TAYLOR: A net level performance analysis of stochastic Petri nets

S. D. HOWISON: See J. N. DEWYNNE

PHIL HOWLETT: An optimal strategy for the control of a train

454

I. HUSAIN: See B. MOND

ANDRZEJ JAJSZCZYK: On nonblocking multiconnection networks composed of digital switching matrices

F. P. KELLY: Fixed point models of loss networks

PHILIP KORMAN, ANTHONY W. LEUNG and SRDJAN STOJANOVIC: Monotone iterations for nonlinear obstacle problem

S. KOSINSKI and B. DUSZCZYK: Normal shock reflection-transmission in rubberlike elastic material

SUNIL KUMAR: The numerical solution of Hammerstein equations by a method based on polynomial collocation

ANTHONY W. LEUNG: See PHILIP KORMAN

D. LUCIC: See W. HENDERSON

K. McNAMARA: See A. L. CAREY

MIN SUN: An evolutionary monotone follower problem in $[0,1]$

B. MOND and I. HUSAIN: Sufficient optimality criteria and duality for variational problems with generalised invexity

R. N. MUKHERJEE: See SHRI RAM YADAV

J. R. OCKENDON: See J. N. DEWYNNE 
M. R. OSBORNE: An interior point method for linear programming

M. R. OSBORNE and R. S. WOMERSLEY: Strong uniqueness in sequential linear programming

R. B. POTTS: See H. H. TAN

A. J. ROBERTS: Appropriate initial conditions for asymptotic descriptions of the long term evolution of dynamical systems

JOHN W. SCHUTZ: The isotropy mappings of Minkowski space-time generate the orthochronous Poincare group

N. F. SMYTH: Propagation of flame fronts

JOSEPH W.-H. SO: Persistence and extinction in a predator-prey model consisting of nine prey genotypes

SRDJAN STOJANOVIC: See PHILIP KORMAN

K. K. TAM: Criticality dependence on data and parameters for a problem in combustion theory, with temperature-dependent conductivity

H. H. TAN and R. B. POTTS: A discrete path/trajectory planner for robotic arms

P. G. TAYLOR: See W. HENDERSON

NICO M. VAN DIJK: Analytic error bounds for approximations of queueing networks with an application to alternate routing

G. C. WAKE: See A. J. HALL

WEIQING XIE: See J. N. DEWYNNE

R. S. WOMERSLEY: See M. R. OSBORNE

SHRI RAM YADAV and R. N. MUKHERJEE: Duality for fractional minimax programming problems

E. M. E. ZAYED: On hearing the shape of an arbitrary doubly-connected region in $R^{2}$

MOSHE ZUKERMAN: Applications of matrix-geometric solutions for queueing performance evaluation of a hybrid switching system 